Вісник ЛНУ імені Тараса Шевченка № 2 (325), 2019

УДК $811.111 ’ 25: 378$

doi: 10.12958/2227-2844-2019-2(325)-322-328

\title{
Березова Л.В.
}

kafedrargflnu@gmail.com

https://orcid.org/0000-0002-8443-8442

кандидат психологічних наук, доцент, кафедра англійської мови

для технічних та агробіологічних спеціальностей,

Національний університет біоресурсів

і природокористування України

Київ, Україна

\section{СУЧАСНІ ПІДХОДИ У ВИКЛАДАННІ ТЕХНІЧНОЇ ТЕРМІНОЛОГІї}

Актуальність. На даний час знання іноземних мов є більш ніж важливим, адже володіння іноземними мовами не лише надає значні можливості для спілкування, а й допомагає людині досягти впевненості у собі, розширити свій кругозір і, навіть, покращити розумові здібності. Це також надає людині переваги під час процесу працевлаштування, саме тому важливим є вміння використовувати професійну лексику іноземною мовою.

Сучасна епоха - епоха науково-технічного прогресу - це невпинний потік наукових досягнень, а отже, такий обсяг науковотехнічної інформації, що вимагає посиленої уваги до розвитку гуманітарних наук. Мова у цьому процесі пов'язана з наукою передусім своїм термінологічним лексичним шаром, у якому відображається соціально організована дійсність.

Поява сучасних технологій, інформатизація і комп'ютеризація переважної більшості суспільних сфер життя ведуть до утворення нових співвідношень між термінологічними системами різних наук. Потреби сучасного науково-технічного спілкування сприяють розвитку i подальшому вдосконаленню мовних засобів передачі інформації, серед яких основну роль відіграють слова та словосполучення, що називають і позначають поняття науки й техніки $[6$, с. 2$]$.

Основний зміст дослідження. Процес бурхливого розвитку термінології $\epsilon$ наслідком утворення якісно нових за структурою термінів, набування нового спеціального знання вже існуючими в інших підмовах термінами, а також теми, які утворилися в результаті переосмислення загальновживаних слів.

Нові терміни можуть утворитися трьома основними способами:

1. Використання внутрішніх ресурсів мови:

а) карбування похідних слів;

б) надання наявним словам нових значень;

в) складання основ;

г) складання словосполучень; 
2. Пряме запозичення терміноелементів:

а) повне запозичення (внутрішня форма разом із зовнішньою);

б) неповне запозичення (тільки внутрішня форма)

3. Конструювання штучних слів.

Навчання іншомовної фахової лексики майбутнього фахівця не може відбуватися стихійно, цей процес вимагає цілеспрямованої та наполегливої праці. Успіх забезпечується вибором відповідних методів навчання як способів упорядкованої роботи викладача й організації навчально-пізнавальної діяльності студентів 3 виконання дидактичних завдань, спрямованих на оволодіння навчальним матеріалом [2, с. 23].

Проблема вивчення термінологічної лексики студентами була і $є$ актуальною у сучасній методичній науці. Термінологічна лексика необхідна студентам насамперед при читанні спеціальних текстів за фахом у вищому навчальному закладі з метою отримання професійної інформації, для ведення професійно-орієнтованої бесіди або дискусії із зарубіжними фахівцями, а також при написанні анотації, реферату чи повідомлення. Тому викладачу англійської мови необхідно розуміти, які основні властивості термінологічної лексики, як семантизувати іiі значення у спеціальних текстах, за допомогою яких вправ активізувати іiі подальше вживання в усному і писемному мовленні.

Очевидно, що вивчення термінологічної лексики при викладанні іноземної мови професійного спрямування буде тим успішнішим й ефективнішим, чим краще зроблений вибір іноземномовного фахового матеріалу, який залучається до навчального процесу. Таким базовим матеріалом $\epsilon$, перш за все, тексти фахового спрямування, які вважаються «джерелом для розширення фахового термінологічного словника», предметом читання та обговорення па заняттях, основою для використання в ситуаціях мовлення, для аудіювання, тобто для цілеспрямованої і продуктивної мовленнєвої діяльності студентів.

В підручниках спеціальної роботи із термінами, як правило, не передбачено: спеціальні терміни включені у вправи, розраховані на закріплення загальної та наукової лексики.

На важливості правильного підбору текстів для задоволення пізнавальних потреб майбутніх спеціалістів наголошує С.К. Фоломкіна. На іiі думку, текст виступає «як основна комунікативна одиниця, якою користується людина в мовленнєвій діяльності» [10]. Деякі дослідники 3 питань термінології вважають, що саме на основі фахових текстів можна відпрацювати визначення, дефініцію для кожного терміна. Тому важко не погодитись із твердженням, що на кожному занятті необхідно здійснювати читання нових, доступних за складністю і змістом текстів $[1,3,5,6]$.

Отже, викладач іноземної мови повинен вирішити, який текст підібрати для читання на занятті. Очевидно, для студента, котрий читає текст - це має бути такий навчальний текст, або текст навчальнонаукового підстилю, який насичений відповідною термінологією, давався 


\section{Вісник ЛНУ імені Тараса Шевченка № 2 (325), 2019}

б до обговорення, до активного опрацювання на занятті, який, крім своєї корисності, ще був би цікавим і зрозумілим для студентів. Як свідчить практика, на початковому етапі вивчення англійської мови професійного спрямування студенти більш зацікавлено й продуктивно опрацьовують термінологію сучасних текстів науково-популярного стилю, періодичних видань за фахом навчання у вищому навчальному закладі. Натомість студенти старших курсів, в яких уже сформовано предметно-понятійну базу, які розуміють терміни рідною мовою, опрацьовують самостійно термінологію 3 неадаптованих автентичних текстів наукового стилю. Такий вид «ознайомлювального» або «пошукового» читання необхідний студентам як для підготовки до написання рефератів, доповідей тощо, так і для їх майбутнього професійного росту, поглиблення знань з фаху. Таким чином студент не лише отримає певну суму знань та навичок, але й навчиться самостійно й оперативно використовувати отриману інформацію у повсякденній діяльності [10].

Аналіз лінгвістичної літератури показав, що особливості терміна як лексичної одиниці визначаються, по-перше, особливостями понять, які виражає термін. Поняття в будь-якій галузі науки і техніки існують не ізольовано, вони пов'язані між собою й утворюють систему.

Спеціальна особливість термінів - тісний, в більшості випадків, однозначний зв'язок 3 поняттям, зв'язок, який зафіксований розміщенням технічного поняття в усій даній системі понять, - $€$ особливістю спеціальних термінів різних галузях науки і техніки.

Як i будь-яка система технічних понять, які відображені термінами рідної або іноземних мов, має ряд особливостей, характерних систем, які можуть бути опорними моментами при пояснені студентам технічної термінології і при складанні вправ. Такі опори можна утворити шляхом об'єднання термінів у групи, основою яких є логіка побудови системи понять, які відображають терміни [3, с. 17].

В роботі Є.Ю. Долматовської пропонується таке групування термінології:

1. На кожній схемі повинні бути представлені терміни, які відображають поняття якоїсь певної категорії, що дає можливість представити у взаємозв'язку систему понять даної категорії і відповідні їі системи термінів рідної та іноземних мов (порівняння).

2. На схемі повинні бути наочно відображені суттєві ознаки понять та виділено загальне та різницю в системах термінів рідної та іноземних мов.

3. Схема повинна бути динамічною: система не може бути представлена як щось готове; терміни іноземної мови слід наносити на схему поступово, після того, як студенти згадали і усвідомили принципи побудови відповідної системи термінології рідної мови.

4. На схемах слід використовувати кольорові сигнали, які вказують на загальне в системі рідної та іноземної мов, стрілки повинні чітко вказувати на порядок чергування понять [3]. 
Вправи:

1. Написати на схему 3 англійськими термінами номера, які відповідають номерам українських термінів які додаються у вигляді списку до схеми.

2. Написати на схему 3 українськими термінами номера англійських термінів із запропонованого списку.

3. Заповнити схему по пом'яті українськими термінами (на схемі тільки всі англійські терміни).

4. Заповнити схему англійськими термінами, яких не вистачає.

5. Читання текстів.

Як показує досвід, така методика повністю виправдовує себе у процесі викладання англійської мови професійного спрямування [3].

Висновки та перспективи. В статті було проаналізовано особливості вивчення термінологічної лексики студентами в сучасній методичній науці. Встановлено, що термінологічна лексика необхідна студентам, насамперед, при читанні спеціальних текстів за фахом у вищому навчальному закладі з метою отримання професійної інформації. Розглянуто, що особливість терміна як лексичної одиниці визначаються, по-перше, особливостями понять, які виражає термін; поняття в будьякій галузі науки і техніки існують не ізольовано, вони пов'язані між собою й утворюють систему. Схарактеризовано групування технічної термінології та на основі якої запропоновано виконання вправ у процесі викладання англійської мови професійного спрямування. Не менш важливим для ефективного засвоєння термінології $\epsilon$ створення викладачем творчої, ділової, дружньої й доброзичливої робочої обстановки на кожному занятті.

\section{Список використаної літератури}

1. Блинова О.И. Термин и его мотивированость: в кн.: Терминология и культура речи. М.: Наука, 1981. 224 с. 2. Вікторова Л.В. Сучасні підходи та інноваційні тенденції у викладанні іноземних мов професійного спрямування. : зб. наук. праць / Наукові записки Національного педагогічного університету імені М. П. Драгоманова. Серія: Педагогічні та історичні науки. / М-во освіти і науки, молоді та спорту України, Нац. пед. ун-т ім. М.П. Драгоманова. К. : Вид-во НПУ ім. М.П. Драгоманова, 2013. Вип. 109. С. 22-28. 3. Долматовская Е.Ю. Методика обучения терминологии по специальности в неязыковом вузе. М.: Наука, 1985. 150 с. 4. Д'яков А.С. та ін. Основи термінотворення: Семантичні та соціолінгвістичні аспекти. К.: Вид. дім «КМ Academia», 2000. 218 с. 5. Карабан В.I. Переклад англійської наукової технічної літератури. Вінниця: Нова книга, 2006. 256 с. б. Луговая А.Л. Методика работы на начальном этапе занятий по технической тематике в неязыковом вузе: автореф. дис. канд. пед. наук. М., 1965. 18 с. 7. Ляховицкий М.В. Методика преподавания иностранных языков. М., 2005. 497 с. 8. Рогач Л.В. Семантична основа лінгвістичних термінів в 
українській та англійській мовах. : автореф. дис... канд. філол. наук: спец. 10.02.15. Київський національний ун-т ім. Тараса Шевченка. К., 2000. 20 с. 9. Панько T.I., Кочан I.M., Мацюк Г.П. Українське термінознаство: підручник. Львів: Світ, 1994. 216 с. 10. Фоломкина С.К. Обучение чтению на иностранном языке в неязыковом вузе : учеб.-метод. пособие. Изд. 2-е, испр. М.: Высшая школа, 2005. - 253 с.

\section{References}

1. Blinova O.I. (1981). Termin i ego motivirovanost: $v$ knige: terminologia I kultura rechi. [The term and its motivation: in the book: Terminology and culture of speech]. M.: Nauka. 224 s. [in Russian]. 2. Victorova L.V. (2013). Suchasni pidhodu ta innivatsiyni tendentsii u vykladanni inizemnykh mov profesiynoho spriamuvannia. [Modern approaches and innovative trends in the teaching of foreign languages in a professional direction]. K.: Vudavnytstvo National Pedagogical Dragomanov University. Issue 109. pp. 22-28 [in Ukrainian]. 3. Dolmatovskaya E.Yu. (1979). Metodyka obuchenyia termynolohyy po spetsyalnosty v neiazykovom vuze. [Technique of training of terminology in the specialty in not language higher education institution]. M.: Vysshaia shkol. 204 s. [in Russian]. 4. D'yakov and another (2000). Osnovy terminotvorennia: Semantychni ta sitsiolingvistychni aspecty. [Fundamentals of terminology: Semantic and sociolinguistic aspects]. K.: Vyd, dim «KM Academia». 218 s. [in Ukrainian]. 5. Karaban V.I. (2006). Pereklad anhliyskoyi naukovoyi tekhnichnoyi literatury. [Translation of English scientific and technical literature]. Vinnytsia: Nova knyha. 256 s. [in Ukrainian]. 6. Lugovaia A.L. (1965). Metodika raboty na nachalnom etape zaniatiy po tekhnicheskoy tematike $\mathrm{v}$ neyazykovom vuze. [Technique of work at the initial stage of studies on technical topics in non-linguistic university]. (Dissertation summary). $18 \mathrm{~s}$. [in Russian]. 7. Liakhovitskii M.V. (2005). Metodika prepodavaniya inistrannykh yazykov. [Methods of teaching foreign languages]. Moscow. 497 s. [in Russian]. 8. Rohach L.V. (2000). Semantychna osnova lingvistychnykh terminiv $\mathrm{v}$ ukrainskiy ta angliyskiy movakh. [Semantic basis of linguistic terms in Ukrainian and English]. (Dissertation summary). $20 \mathrm{~s}$. [in Ukrainian]. 9. Panko T.I., Kochan I.M., Matsiuk H.P. (1994). Ukrainske terminoznastvo. [Ukrainian term knowledge]. Lviv: Svit. 216 s. [in Ukrainian]. 10. Folomkina S.K. (2005). Obycheniye chteniyu na innostrannom yazyke $\mathrm{v}$ neyazykovom vyze. [Teaching reading in foreign language in non-linguistic university]. M.: Vysshaya shkola. 253 s. [in Russian].

\section{Березова Л.В. Сучасні підходи у викладанні технічної термінології \\ В статті було проаналізовано особливості вивчення термінологічної лексики студентами в сучасній методичній науці. Встановлено, що термінологічна лексика необхідна студентам,}


насамперед, при читанні спеціальних текстів за фахом у вищому навчальному закладі 3 метою отримання професійної інформації. Розглянуто, що особливість терміна як лексичної одиниці визначаються особливостями понять. Схарактеризовано групування технічної термінології. Система технічних понять, яка відображена термінами рідної або іноземних мов, має ряд особливостей, характерних систем, що $\epsilon$ опорними моментами при навчанні термінології. Для кращого засвоєння термінів пропонується об'єднувати їх в групи, будуючи схеми, основою яких є логіка побудови системи понять.

Ключові слова: іншомовна фахова компетентність, термінологічна лексика, система технічних понять, термін.

\section{Березовая Л.В. Современные подходы в преподавании технической терминологии \\ В статье были проанализированы особенности изучения} терминологической лексики студентами в современной методической науке. Установлено, что терминологическая лексика необходима студентам, прежде всего, при чтении специальных текстов по специальности в высшем учебном заведении с целью получения профессиональной информации. Рассмотрены, что особенность термина как лексической единицы определяются особенностями понятий. Охарактеризован группировки технической терминологии. Система технических понятий, которая отражена сроками родной или иностранных языков, имеет ряд особенностей, характерных систем, являются опорными моментами при обучении терминологии. Для лучшего усвоения сроков предлагается объединять их в группы, строя схемы, основой которых является логика построения системы понятий.

Ключевые слова: иноязычная профессиональная компетентность, терминологическая лексика, система технических понятий, термин.

\section{Berezova L.V. Modern approaches in teaching of technical terminology}

In the paper the features of studying of terminological lexicon by students in modern methodical science were analysed. It is established that terminological lexicon is necessary for students, first of all, when reading special texts on the specialty in higher educational institution for the purpose of obtaining professional information. The lecturer of a foreign language has to solve, to pick up the text for reading on speciality, for a student who reads the text, it has to be such educational text or text of educational and scientific substyle which is sated with the corresponding terminology, this text has to be discussed and activated and be interesting and clear for students. When studying English of the professional direction students are interested in productively studying of modern texts terminology of popular scientific style, periodicals as training in a higher educational institution. It is considered that feature of a term as lexical unit is defined by features of concepts. The groups 
of technical terminology are characterized. The exercises in the process of teaching English of the professional direction is offered. The system of technical notions which are show by terms of native and foreign languages has some particularities, character systems which are the base moments by teaching terms. For better mastering of terms, we offer to combine them in groups building schemes, main word of which is logic of building the notions system. Creation by the teacher of creative, business, friendly and benevolent working atmosphere on each stage of work is important for effective learning of terminology.

Key words: foreign language competence on speciality, terminology vocabulary, system of technical concepts, terms.

Стаття надійшла до редакції 27.03.2019 р.

Стаття прийнята до друку 28.03.2019 р.

Рецензент - к.пед.н, доц. Пономаренко О.Г. 